\title{
Pleiotropic Aspartate Taxis and Serine Taxis Mutants of Escherichia coli
}

\author{
By ROBERT W. READER,* WUNG-WAI TSO, $†$ MARTIN S. SPRINGER, \\ MICHAEL F. GOY $\ddagger$ AND JULIUS ADLER \\ Departments of Biochemistry and Genetics and the $\$$ Neurosciences Training Program, \\ College of Agricultural and Life Sciences, University of Wisconsin-Madison, Madison, \\ Wisconsin 53706, U.S.A.
}

(Received 8 August 1978)

\begin{abstract}
Mutants that at one time were thought to be specifically defective in taxis toward aspartate and related amino acids (tar mutants) or specifically defective in taxis toward serine and related amino acids ( $t s r$ mutants) are now shown to be pleiotropic in their defects. The tar mutants also lack taxis toward maltose and away from $\mathrm{Co}^{2+}$ and $\mathrm{Ni}^{2+}$. The $t s r$ mutants are altered in their response to a variety of repellents. Double mutants (tar tsr) fail in nearly all chemotactic responses. The tar and $t s r$ mutants provide evidence for two complementary, converging pathways of information flow: certain chemoreceptors feed information into the tar pathway and others into the $t s r$ pathway. The tar and $t s r$ products have been shown to be two different sets of methylated proteins.
\end{abstract}

\section{INTRODUCTION}

Workers in this laboratory have described bacterial mutants defective in taxis toward aspartate and related amino acids (Mesibov \& Adler, 1972) and other mutants defective in taxis toward serine and related amino acids (Hazelbauer et al., 1969; Mesibov \& Adler, 1972). These defects were interpreted in terms of the chemoreceptor theory, which states that in chemotaxis chemicals are detected by specific receptors (Adler, 1969). Thus the aspartate taxis mutants seemed to be defective in an aspartate receptor and the serine taxis mutants in a serine receptor. Such an interpretation has proved correct for a number of specific taxis mutants; for example, galactose taxis mutants indeed lack a galactose receptor - the galactose binding protein (Hazelbauer \& Adler, 1971).

Subsequently, it has been shown that the aspartate taxis mutants and serine taxis mutants have additional taxis defects (Mesibov \& Adler, 1972; Tso \& Adler, 1974; this report). Hence these mutants are not specific taxis mutants, and we shall refer to them as 'pleiotropic taxis mutants'. The aspartate taxis mutants will be referred to as tar mutants, for taxis defects towards aspartate and certain repellents, and the serine taxis mutants as $t s r$, a name first used by Parkinson (1975), for taxis defects towards serine and certain repellents.

In this article we describe our present knowledge of these two kinds of mutants. We also present evidence that the tar mutants and the $t s r$ mutants are each defective in one or other of two pathways through which most chemoreceptors channel their information. Each pathway converges upon a different component; these components are proteins that can be methylated, and they have been described in detail elsewhere (Silverman \& Simon, 1977; Springer et al., 1977).

* Present address: University of Toronto Medical School, Canada.

$\uparrow$ Present address: Department of Biochemistry, Chinese University of Hong Kong. 


\section{METHODS}

Bacterial strains. The tar and $t s r$ mutants, listed in Table 1, were derived from Escherichia coli $\mathrm{K} 12$ strains that are wild-type for chemotaxis. These parent strains have been described previously: AW405 (Mesibov \& Adler, 1972); AW574 (Ordal \& Adler, 1974a); and AW546, a His- derivative of B275 (Hazelbauer \& Adler, 1971).

The double mutants (tar tsr) were constructed by transferring the chemotaxis defect of the $t s r$ mutant AW518 into the tar mutant AW539 via P1 cotransduction with $t h r$ from $t h r^{+}$derivatives of the $t s r$ mutant. Two independent double mutants having identical properties were isolated: AW565 and AW569

Chemotaxis assays. Capillary assays (Adler, 1973) were used for positive chemotaxis. Semi-solid agar swarm plates were used for demonstrating positive chemotaxis to metabolizable chemicals (Adler, 1966). For negative chemotaxis, the chemical-in-plug assay, the chemical-in-capillary assay, the chemical-in-pond assay, and the chemical-in-plate assay (Tso \& Adler, 1974) were used. Temporal assays for positive and negative chemotaxis were carried out according to the procedures described by Koshland's group (Macnab \& Koshland, 1972; Tsang et al., 1973), except that the bacteria and the chemical to be tested were mixed on a microscope slide. Addition of repellents or attractants resulted in periods of enhanced or suppressed tumbling, respectively. L-Methionine $\left(10^{-6}\right.$ to $\left.10^{-4} \mathrm{M}\right)$ was included in all taxis assays involving Met- $^{-}$ bacteria (Adler, 1973).

Complementation tests. For complementation of tsr mutants, $\mathrm{F}^{\prime}$ factors carrying $t s r$ were prepared as follows. The $t s r$ marker was introduced into Hfr Hayes $\mathrm{ser} B, t h r^{+}, \mathrm{leu}^{+}, \mathrm{lac}^{+}$by joint transduction (Ordal \& Adler, 1974a) with $s e r B^{+}$. The resulting $t s r, \operatorname{ser} B^{+}, t h r^{+}, l e u^{+}, l a c^{+}$Hfr was then mated with a $s e r B^{+}, t h r$, leu, $l a c, r e c A, s t r^{\mathrm{R}} \mathrm{F}^{-}$strain in the presence of streptomycin, and $\operatorname{ser} B^{+}, t h r^{+}, l e u^{+}, l a c^{+}$bacteria were isolated. $\mathrm{F}^{\prime}$-carrying strains were those able to transfer $t s r, s e r B^{+}, t h r^{+}, l l e^{+}$and $l a c^{+}$into $\mathrm{F}^{-}$recA recipients.

To test for complementation, $t s r$ mutants in their $\mathrm{F}^{-} r e c A$, $n a l^{\mathrm{R}}$, $t h r$, leu, lac form were mated with strains carrying an $\mathrm{F}^{\prime}$ factor that bore one of several tsr loci. After selection of the $t h r^{+}, l e u^{+}, l a c^{+}, n a l^{\mathbf{R}}$ partial diploids in the presence of nalidixic acid, complementation was assessed by their ability to carry out serine taxis on a tryptone swarm plate (Adler, 1966), modified to contain only $2 \mathrm{~g}$ tryptone $\mathbf{1}^{-1}$ (instead of the usual $10 \mathrm{~g} \mathrm{l}^{-1}$ ) to increase the speed of the serine ring, $10^{-3} \mathrm{M}$-L-aspartate to retard the aspartate ring (as in Fig. 5), $1 \mathrm{~g} \mathrm{NaCl} 1^{-1}$ and $2.5 \mathrm{~g}_{\text {agar }} 1^{-1}$.

\section{RESULTS}

\section{Pleiotropic aspartate taxis (tar) mutants}

Positive chemotaxis properties. The first aspartate taxis mutant to be described (Mesibov \& Adler, 1972), AW539, appeared to lack taxis only toward aspartate and related amino acids; taxis was evident for all other attractants that had been tested (Mesibov \& Adler, 1972 ), including serine and $\alpha$-aminoisobutyrate, ribose and galactose (Mesibov \& Adler, 1972; Fig. 1, this report). Subsequently, however, taxis toward maltose was tested and found to be abnormal (Fig. 1). In addition, certain repellent responses were found to be abnormal (see below). Thus AW539 is what we sháll call a 'pleiotropic aspartate taxis mutant' or a 'tar mutant', not a specific aspartate taxis mutant.

For the tar mutant AW539, the defects in taxis toward aspartate and maltose were indicated on an aspartate swarm plate (Fig. 2) and a maltose swarm plate (Fig. 3), respectively. The mutant, unlike its parent, did not form a ring of bacteria showing taxis toward aspartate or maltose.

All the other aspartate taxis mutants studied so far were also found to be pleiotropic (tar) mutants (Table 2). All the mutants tested appeared to belong to a single complementation group: mutants $1,5,6,7$ and 8 failed to complement with mutation 4 carried on a lambda phage, according to studies by $\mathrm{H}$. Kondoh (unpublished results).

Negative chemotaxis properties. AW539, the tar mutant that was tested most extensively for negative chemotaxis, was repelled normally by acetate, indole, leucine, benzoate and low $\mathrm{pH}\left(\mathrm{H}^{+}\right)$(Table 3). These chemicals represent five different repellent classes (Tso \& Adler, 1974). In contrast, $\mathrm{Co}^{2+}$ and $\mathrm{Ni}^{2+}$, which are members of a different repellent class (Tso \& Adler, 1974), elicited little if any response in AW539 (Table 3 and Fig. 4). Thus, mutant AW539 retains certain negative taxes but is defective for others.

Pleiotropic aspartate taxis (tar) mutants other than AW539 were not tested extensively 
Table 1. Derivation of tar and tsr mutants

Mutant

$\begin{array}{ccccc}\begin{array}{c}\text { Allele } \\ \text { no. }\end{array} & \begin{array}{c}\text { Strain } \\ \text { no. }\end{array} & \text { Parent strain* } & \begin{array}{c}\text { Isolation } \\ \text { method }\end{array} & \text { Mutagen } \\ \begin{array}{c}\text { tar mutants } \\ 1\end{array} & \text { AW539 } & \text { AW405 } & 1 & \text { NTG } \\ 2 & \text { AW631 } & \text { AW405 } & 1 & \text { NTG } \\ 3 & \text { AW632 } & \text { AW405 } & 1 & \text { NTG } \\ 4 & \text { AW633 } & \text { AW405 } & 1 & \text { NTG } \\ 5 & \text { AW634 } & \text { AW405 } & 2 & \text { none } \\ 6 & \text { AW635 } & \text { AW405 } & 2 & \text { none } \\ 7 & \text { AW636 } & \text { AW546 } & 3 & \text { NTG } \\ 8 & \text { AW637 } & \text { AW574 } & 3 & \text { EMS } \\ t s r \text { mutants } & & & & \\ 1 & \text { AW518 } & \text { AW405 } & 2 & \text { none } \\ 2 & \text { AW638 } & \text { AW405 } & 2 & \text { none } \\ 3 & \text { AW639 } & \text { AW405 } & 1 & \text { NTG } \\ 4 & \text { AW640 } & \text { AW405 } & 1 & \text { NTG } \\ 5 & \text { AW641 } & \text { AW405 } & 1 & \text { none } \\ 6 & \text { AW642 } & \text { AW405 } & 1 & \text { none } \\ 7 & \text { AW643 } & \text { AW405 } & 1 & \text { none } \\ 8 & \text { AW644 } & \text { AW405 } & 1 & \text { NTG } \\ 9 & \text { AW645 } & \text { AW405 } & 1 & \text { NTG } \\ 10 & \text { AW646 } & \text { AW405 } & 1 & \text { NTG } \\ 11 & \text { AW647 } & \text { AW546 } & 3 & \text { NTG } \\ 12 & \text { AW648 } & \text { AW574 } & 3 & \text { EMS } \\ 13 & \text { AW649 } & \text { AW574 } & 3 & \text { EMS } \\ 14 & \text { AW650 } & \text { AW574 } & 3 & \text { EMS } \\ 15 & \text { AW651 } & \text { AW574 } & 3 & \text { EMS } \\ 16 & \text { AW652 } & \text { AW574 } & 3 & \text { EMS } \\ 17 & \text { AW653 } & \text { AW574 } & 3 & \text { EMS }\end{array}$

* See Methods.

$\dagger$ Method 1: as in Mesibov \& Adler (1972), using $3 \times 10^{-4} \mathrm{M}-\mathrm{L}-$ aspartate for tar mutants and $10^{-3} \mathrm{M}-\mathrm{L}-$ serine for $t s r$ mutants. Method 2: as in Armstrong et al. (1967). Method 3: as in Ordal \& Adler (1974a), except that tryptone swarm plates (Hazelbauer et al., 1969) were used.

$¥$ The mutagens $N$-methyl- $N^{\prime}$-nitro- $N$-nitrosoguanidine (NTG) and ethyl methanesulphonate (EMS) were used as described by Armstrong et al. (1967) and Ordal \& Adler (1974a), respectively.

for negative chemotaxis, but the available data (not shown) indicate a response pattern similar to that of AW539.

Reversion studies From mutants 2, 3 and 8 an aspartate taxis revertant was isolated from a ring that eventually formed spontaneously on an aspartate swarm plate, and from mutant 8 a maltose taxis revertant was isolated from a ring that eventually formed spontaneously on a maltose swarm plate. All these revertants showed normal taxis toward aspartate and maltose on swarm plates, judged by normal ring formation. Thus the two chemotaxis defects co-revert, indicating that the two defects result from a single mutation. Attempts to isolate revertants of AW539 were unsuccessful.

\section{Pleiotropic serine taxis (tsr) mutants}

Positive chemotaxis properties. The original serine taxis mutant (Hazelbauer et al., 1969; Mesibov \& Adler, 1972), AW518, appeared to be defective in taxis only toward serine and related amino acids, for example, $\alpha$-aminoisobutyrate; its response to all other attractants tested was normal or above normal (Mesibov \& Adler, 1972; Figs 1, 2, 3, 5 and 6, this report). However, the response of this mutant to a number of repellents was found to be abnormal (Mesibov \& Adler, 1972; Tso \& Adler, 1974; see below). Therefore, we shall refer to such a mutant as a 'pleiotropic serine taxis mutant' or a 'tsr mutant', not a specific serine taxis mutant. 

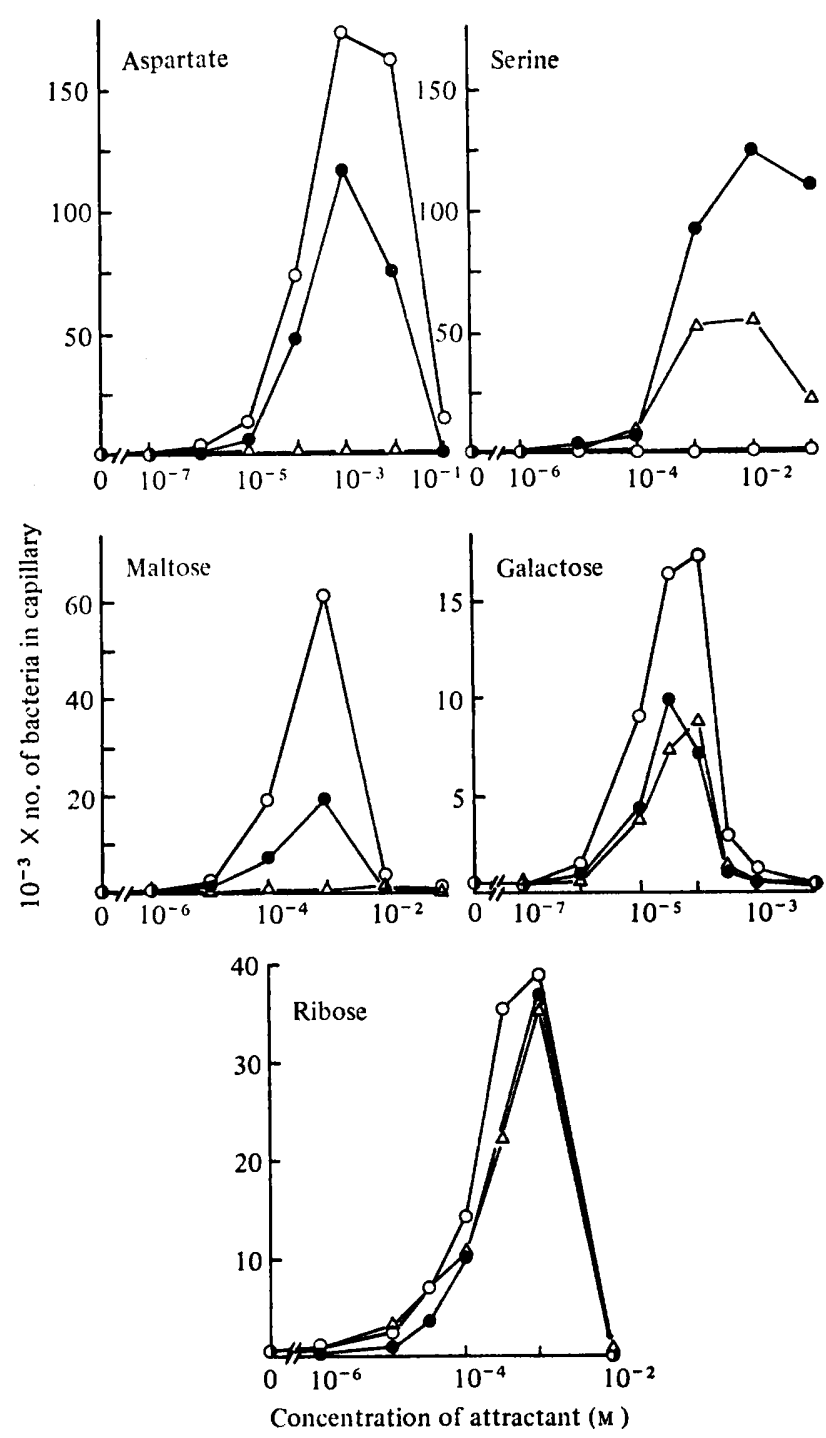

Fig. 1. Chemotactic responses to several attractants of the chemotactically wild-type parent AW405 ( $\odot$ ), the tar mutant AW539 ( $\triangle$ ) and the $t s r$ mutant AW518 $(O)$, measured by capillary assays at a bacterial concentration of $4 \times 10^{6}$ cells $\mathrm{ml}^{-1}\left(A_{590} 0.005\right)$. Where available (Mesibov \& Adler, 1972), results of assays at a bacterial concentration 20 times higher are in fair agreement with these. The bacteria were grown in glycerol-minimal medium (Adler, 1973) when they were to be tested for responses to L-aspartate and L-serine and also for D-galactose (since the strains are $\left.\mathrm{Gal}^{-}\right)$. Bacteria to be tested for responses to maltose and D-ribose were grown in the respective sugar-minimal medium (Adler, 1973). For AW405, the results for the amino acids and ribose are the average of two experiments.

We have studied 16 additional similar mutants that are attracted well by aspartate but are defective in response to serine in a capillary (Table 4) and fail to make a serine ring on a swarm plate (Hazelbauer et al., 1969; Fig. 5, this report). All 17 mutants belong to a single complementation group (see below). The additional mutants have received limited study of their attraction by sugars: eleven tested were attracted into capillaries containing glucose (Table 4); two tested were attracted into capillaries containing maltose (data not shown); three tested exhibited normal responses in swarm plates containing D-fructose, D-galactose, 


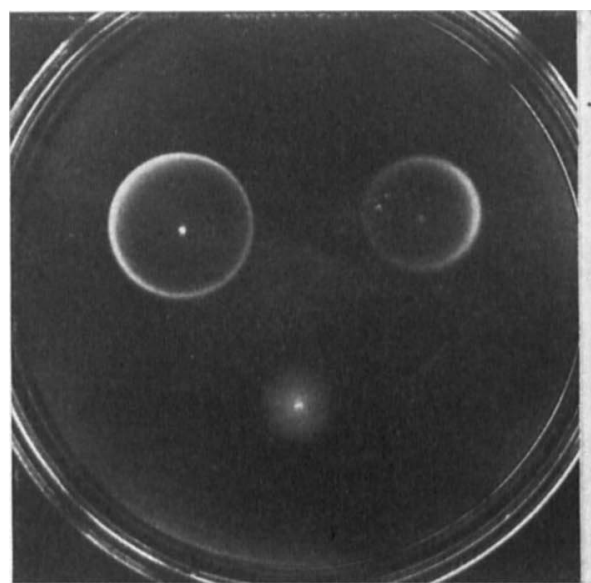

Fig. 2

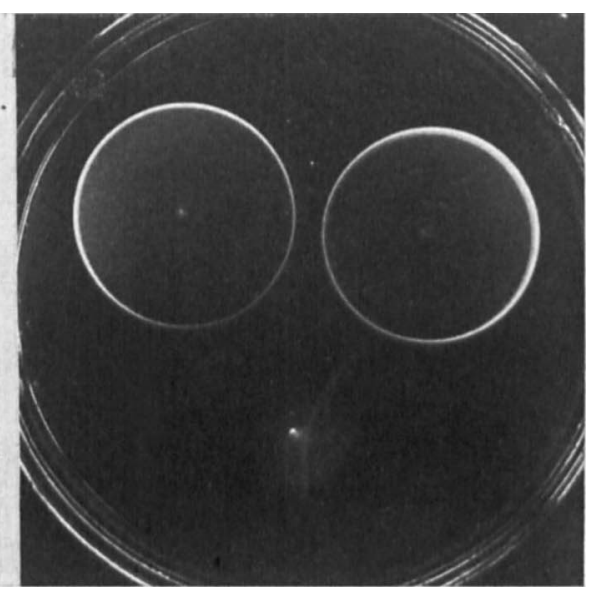

Fig. 3

Fig. 2. Use of a swarm plate as an indication of taxis toward L-aspartate. Note the aspartate-consuming ring (as in Adler, 1966), indicative of aspartate taxis, in the parental strain AW405 (left) and the $t s r$ mutant AW518 (right), and the decreased spreading and absence of a ring in the tar mutant AW539 (bottom). The medium contained $10^{-4} \mathrm{M}-\mathrm{L}$-aspartate and, as an extra carbon and energy source, $10^{-3} \mathrm{M}$-glucuronate or (in other experiments) $10^{-3} \mathrm{M}$-glycerol. Other additions and procedures were as described in Adler (1966). Incubation was for $12 \mathrm{~h}$ at $35^{\circ} \mathrm{C}$.

Fig. 3. Use of a swarm plate as an indication of taxis toward maltose. Note the maltose-consuming ring at the edge of the swarm, indicative of maltose taxis, in the parental strain AW405 (left) and the tsr mutant AW518 (right), and the decreased spreading and absence of a ring in the tar mutant AW539 (bottom). The medium contained $2 \times 10^{-4}$ M-maltose. Other additions and procedures were as described in Adler (1966). Incubation was for $20 \mathrm{~h}$ at $35^{\circ} \mathrm{C}$.

\section{Table 2. Chemotactic responses of tar mutants to various attractants}

Chemotaxis was measured by the capillary assay (Adler, 1973) at a bacterial concentration of $4 \times 10^{6}$ cells $\mathrm{ml}^{-1}$. The results (average of several experiments) show the mutant response compared with that of its parent at the attractant concentration which elicited the peak response from the parent. Attractant concentrations and peak responses of the parental strains AW405, AW574 and AW546 were, respectively: $10^{-3} \mathrm{M}$-L-aspartate, 120000,120000 and $140000 ; 10^{-3} \mathrm{M}-\mathrm{maltose}, 45000$, 50000 and $35000 ; 3 \times 10^{-4} \mathrm{M}$ (AW405) or $10^{-3} \mathrm{M}-\mathrm{D}-$-ribose, 31000,70000 and $70000 ; 10^{-2} \mathrm{M}-\mathrm{L}-$ serine, 140000,70000 and 170000 . The bacteria were grown in minimal salts medium (Adler, 1973) with the attractant sugar as carbon source, or with glycerol for the amino acid attractants.

Mutants 1 and 8 , the only ones tested with galactose in the capillary assay, gave responses of 90 and $35 \%$, respectively, of their parents.

Percentage of parental response to:

$\begin{array}{lcccc}\text { tar mutant } & \text { Aspartate } & \text { Maltose } & \text { Ribose } & \text { Serine } \\ 1 \text { (AW539) } & 0 \cdot 4 & 5 & 90 & 73 \\ 2 & 0 \cdot 1 & 1 & 6 & 21 \\ 3 & 0 \cdot 4 & 5 & 32 & 36 \\ 4 & 0 \cdot 5 & 10 & 52 & 86 \\ 5 & 0 \cdot 3 & 5 & 190 & 68 \\ 6 & 0 \cdot 3 & 4 & \text { ND } & 57 \\ 7 & 0 \cdot 3 & 5 & 57 & 85 \\ 8 & 0 \cdot 1 & 1 & 16 & 51\end{array}$

ND, No data available. 


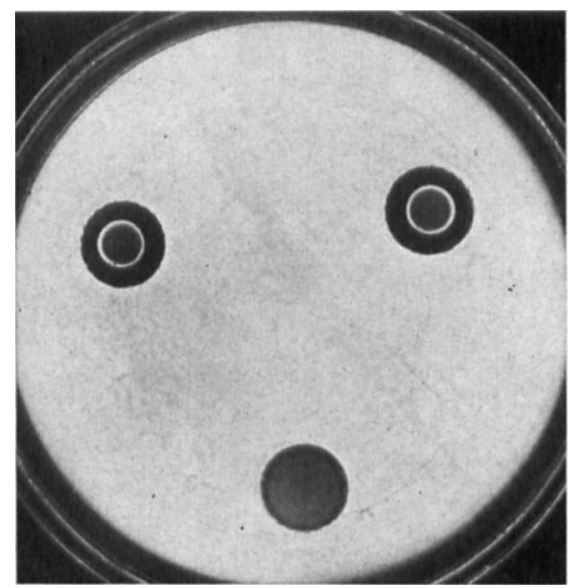

Fig. 4. Use of the chemical-in-plate assay as an indication of negative chemotaxis to $\mathrm{Co}^{2+}$. The three wells each contained a suspension of bacteria $\left(A_{590} 0.3\right)$ in $0.2 \%(\mathrm{w} / \mathrm{v})$ agar but without $\mathrm{CoSO}_{4}$; the rest of the plate (the light surface) contained $3 \%(\mathrm{w} / \mathrm{v})$ agar and $10^{-2} \mathrm{M}-\mathrm{CoSO}_{4}$, but no bacteria. Other additions and procedures were as described in Tso \& Adler (1974). Note the ring of bacteria, indicative of repulsion by $\mathrm{Co}^{2+}$, in the wells containing the parental strain AW405 (left) and the tsr mutant AW518 (right), and the abnormality of the ring in the well containing the tar mutant AW539 (bottom). Incubation was for $27 \mathrm{~min}$ at room temperature.

\section{Table 3. Chemotactic responses to repellents}

Chemotactic responses were assayed by the following methods: (a) Chemical-in-plug assay. Concentrations of chemicals used in the plug were: $10^{-1} \mathrm{M}$-sodium acetate, $10^{-1} \mathrm{M}$-sodium benzoate, $3 \times 10^{-3} \mathrm{M}$-indole, $10^{-1} \mathrm{M}$-L-leucine, $10^{-3} \mathrm{M}^{-N_{i S O}}{ }_{4}, 10^{-2} \mathrm{M}-\mathrm{CoSO}_{4}$.

(b) Chemical-in-capillary assay.

(c) Chemical-in-pond assay [both the centre and right panels of Fig. 3 of Tso \& Adler (1974) were used in all cases].

(d) A special version of chemical-in-plug method. A plug of $3 \%$ agar containing a centre well was embedded in $1 \%$ methylcellulose containing bacteria; then $0.33 \mathrm{M}-\mathrm{H}_{3} \mathrm{PO}_{4}$ was added to the centre well.

(e) Temporal assay (Macnab \& Koshland, 1972; Tsang et al., 1973). Final concentration of each chemical, duration of response in the wild type (in seconds \pm average deviation, with number of experiments indicated in parentheses) and duration of response in the tar mutant (in seconds \pm average deviation, with number of experiments indicated in parentheses) were, respectively: $17 \mathrm{mM}$ sodium acetate, $16 \pm 1$ (2), 17 (1); 33 mM-sodium benzoate, $32 \cdot 5 \pm 2 \cdot 5$ (2), $55 \pm 5$ (2); $0 \cdot 33$ mM-indole, $30 \pm 5$ (6), $37 \pm 5$ (4); 33 mm-L-leucine, $14 \pm 1$ (4), 14.5 \pm 0.5 (3); 0.5 mM-CoSO, 25 (1), 0 (1);

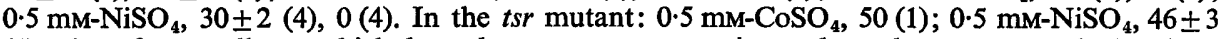
(4); data for repellents which have become attractants in $t s r$ have been presented elsewhere (Muskavitch et al., 1978). In the double mutant, addition of indole transiently caused a small fraction of the cells to display a slight increase in tumbling frequency; this does not represent a full repellent response.

$\begin{array}{lllll}\text { Repellent } & \begin{array}{c}\text { Wild type } \\ \text { (AW405) }\end{array} & \begin{array}{c}\text { tar mutant } \\ \text { (AW539) }\end{array} & \begin{array}{c}\text { Response } \\ \text { (AW518) }\end{array} & \begin{array}{c}\text { tar tsr double mutant } \\ \text { (AW565, AW569) }\end{array} \\ \text { Acetate } & \text { repulsion }(a, e) & \text { repulsion }(a, e) & \text { attraction }(b, e) & \text { no repulsion }\left(a, e^{*}\right) \\ \text { Indole } & \text { repulsion }(a, e) & \text { repulsion }(a, e) & \text { attraction }(b, e) & \text { slight repulsion }(a, e) \\ \text { Leucine } & \text { repulsion }(a, e) & \text { repulsion }(a, e) & \text { no response }(b, e) & \text { no repulsion }\left(a, e^{*}\right) \\ \text { Benzoate } & \text { repulsion }(a, e) & \text { repulsion }(a, e) & \text { attraction }(b, e) & \text { no repulsion }\left(a, e^{*}\right) \\ \mathrm{H}^{+} & \text {repulsion }(c, d) & \text { repulsion }(c, d) & \text { no response }(c, d) & \text { ND } \\ \mathrm{Co}^{2+} & \text { repulsion }(a, e) & \text { no response }(a, b, e) & \text { repulsion }(a, e) & \text { no repulsion }\left(e^{*}\right) \\ \mathrm{Ni}^{2+} & \text { repulsion }(a, e) & \text { no response }(a, b, e) & \text { repulsion }(a, e) & \text { no repulsion }\left(e^{*}\right)\end{array}$

ND, No data available.

* The spontaneous tumbling frequency of the double mutant was so low that it would have been hard to detect suppression of tumbling (i.e. attraction). 


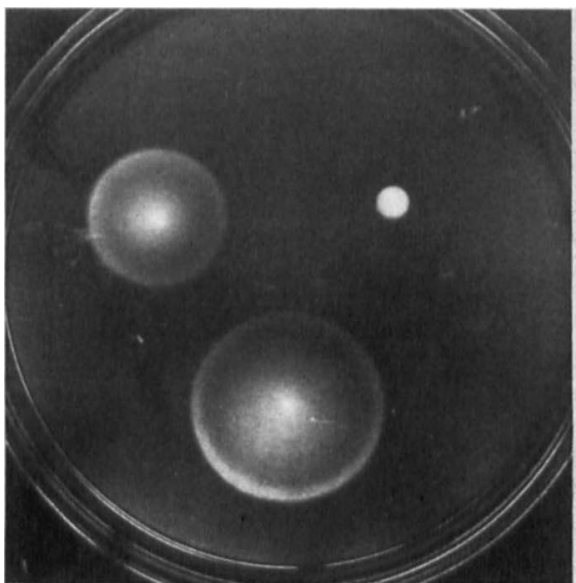

Fig. 5

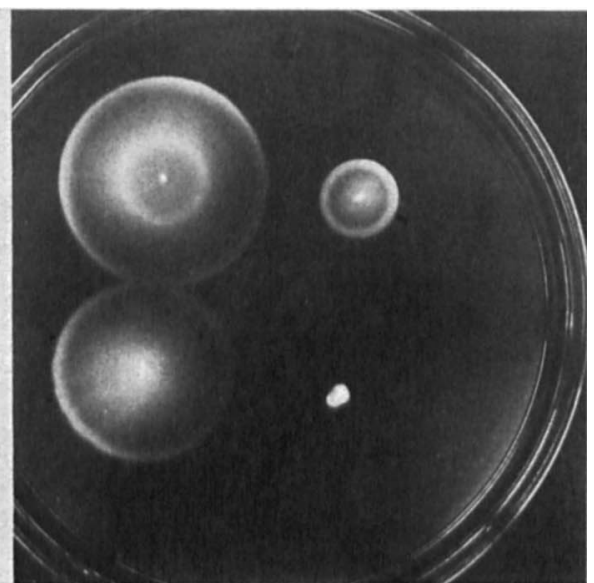

Fig. 6

Fig. 5. Use of a swarm plate as an indication of taxis toward L-serine. Note the spreading and the serine-consuming ring at the edge of the swarm, indicative of serine taxis, in the parental strain AW405 (left) and the tar mutant AW539 (bottom), and the decreased spreading and absence of a ring in AW518 (right). The medium contained tryptone broth as in Hazelbauer et al. (1969), supplemented with $10^{-2} \mathrm{M}$-L-aspartate to retard the aspartate ring (compare with Fig. 6). Incubation was for $6.5 \mathrm{~h}$ at $35^{\circ} \mathrm{C}$.

Fig. 6. Use of a tryptone broth swarm plate as an indication of taxis toward L-serine and Laspartate. Note the outer serine-consuming ring and the inner aspartate-consuming ring, indicative of serine and aspartate taxis, respectively, in the parental strain AW405 (top left). Only the aspartateconsuming ring is present in the tsr mutant AW518 (top right), only the serine-consuming ring is present in the tar mutant AW539 (bottom left), and neither is present in the tar tsr double mutant AW569 (bottom right). Incubation was for $6 \mathrm{~h}$ at $30^{\circ} \mathrm{C}$ in medium containing tryptone broth as described in Hazelbauer et al. (1969), except that the agar concentration was $0.3 \%$. Photo courtesy of $\mathbf{H}$. Kondoh.

\section{Table 4. Chemotactic responses of tsr mutants to various chemicals}

In experiments with attractants, the procedures were the same as in Table 2, except that in all glucose assays and in the serine assay for mutants 1 to 11 , the bacterial concentration was $8 \times 10^{7} \mathrm{cells}^{-1}$.

In experiments with repellents, lack of repulsion is indicated by - . With acetate, there was actually attraction (see text); failure to be repelled by sodium acetate was shown by the chemicalin-plug assay or the chemical-in-plate assay or by attraction into a capillary containing sodium acetate. Defective $\mathrm{H}^{+}$taxis was shown by lack of attraction of bacteria at $\mathrm{pH} 5.0$ into a capillary at $\mathrm{pH} 7 \cdot 0$. Failure to be repelled by L-leucine was shown by the chemical-in-plug assay.

Percentage of parental response to attractants:

Response to repellents:

$\begin{array}{lcccccc}\text { tsr mutant } & \text { Serine } & \text { Aspartate } & \text { Glucose } & \text { Acetate } & \text { H }^{+} & \text {Leucine } \\ 15 & 0 & 52 & \text { ND } & - & \text { ND } & - \\ 14 & 0 & 87 & \text { ND } & - & \text { ND } & - \\ 12 & 0 & 93 & \text { ND } & - & \text { ND } & - \\ 16 & 0 & 147 & \text { ND } & - & \text { ND } & - \\ 17 & 0 & 215 & \text { ND } & \text { ND } & \text { ND } & \text { ND } \\ 13 & 1 & 72 & \text { ND } & - & \text { ND } & - \\ 1 \text { (AW518) } & 1 & 103 & 267 & - & - & - \\ 11 & 1 & 109 & 125 & \text { ND } & \text { ND } & \text { ND } \\ 7 & 1 & 125 & 166 & - & - & \text { ND } \\ 3 & 2 & 52 & 176 & - & - & - \\ 5 & 2 & 103 & 142 & - & - & - \\ 10 & 2 & 115 & 224 & - & - & \text { ND } \\ 4 & 3 & 129 & 168 & \text { ND } & - & - \\ 9 & 4 & 128 & 150 & - & - & \text { ND } \\ 6 & 4 & 137 & 211 & - & - & \text { ND } \\ 2 & 5 & 95 & 162 & \text { ND } & - & \text { ND } \\ 8 & 5 & 145 & 189 & - & - & \text { ND }\end{array}$

ND, No data available. 
D-glucose, maltose or D-ribose (data not shown). In nearly all cases the response to sugars was greater for $t s r$ mutants than for their parents, as was found originally with AW518 (Mesibov \& Adler, 1972; Fig. 1 and Table 4, this report). Furthermore, every one of the serine taxis mutants was abnormal in negative chemotaxis (see below) and is, therefore, a pleiotropic ( $t$ sr) mutant.

Negative chemotaxis properties. The tsr mutant AW518 was repelled normally by $\mathrm{Co}^{2+}$ and $\mathrm{Ni}^{2+}$ (Table 3 and Fig. 4), but not by acetate, benzoate, indole or leucine, as previously reported (Tso \& Adler, 1974) or by $\mathrm{H}^{+}$. Thus, certain negative taxes are retained while others are lost. A remarkable finding, reported in detail elsewhere (Muskavitch et al., 1978), is that AW518 is attracted by a number of chemicals that normally repel: acetate, benzoate and indole (Table 3).

All that has been described for negative chemotaxis in AW518 is also true for the additional serine taxis mutants as far as they have been tested (Table 4). Thus, 14 of the additional serine taxis mutants have been tested and found abnormal for at least one of the negative taxes that is altered in AW518.

Reversion studies. On a tryptone swarm plate, serine taxis mutants spread abnormally owing to their failure to form a ring of bacteria showing taxis toward serine (Hazelbauer et al., 1969; Fig. 6, this report). Revertants that did form such a ring were not found for AW518, but they were obtained, both spontaneously and following treatment with the mutagen ethyl methanesulphonate, for five other strains examined (mutants 12 to 16). From each of the five mutants, the revertants that had regained full serine taxis had also regained normal negative taxis away from acetate and leucine, the two repellents tested. This co-reversion indicates that the several defects in each mutant are due to a single mutation.

Complementation. The $17 \mathrm{ts}$ mutants studied all fall into a single complementation group: they failed to complement with $\mathrm{F}^{\prime}$ strains carrying one of three $t s r$ mutations (those of strains AW518, 12 and 14). The tsr mutation is not dominant: all 17 mutants did show complementation with an $\mathrm{F}^{\prime}$ strain that carried no taxis mutation, and the parental strains showed serine taxis even when they harboured $\mathrm{F}^{\prime}$ episomes carrying each of the three $t s r$ mutations.

\section{tar tsr double mutant}

Double mutants, containing both the tar mutation of AW539 and the $t s r$ mutation of AW518, were prepared as described in Methods. In such double mutants all chemotactic responses are missing or much reduced. Thus they behave like generally non-chemotactic mutants (che mutants), but differ in one important respect: their tumbling frequency is appreciable although considerably less than normal, while che mutants either fail to tumble or tumble incessantly (Parkinson, 1977; Warrick et al., 1977).

Positive chemotaxis properties. In the double mutants, loss of aspartate and serine taxis was expected from the characteristics of the single mutants and this was found. On a tryptone swarm plate, the double mutants gave only very slight spreading (Fig. 6) like generally nonchemotactic mutants (Armstrong et al., 1967); the outer, or serine-consuming, ring and the inner, or aspartate-consuming, ring produced by chemotactically wild-type $E$. coli (Adler, 1966) were missing. The double mutant was not attracted into capillaries containing aspartate or serine (data not shown).

Surprisingly, the double mutants appeared to be defective in taxis toward sugars that attracted the single mutants well. Unlike the single mutants, the double mutants made extremely small rings on D-glucose and D-ribose swarm plates (data not shown), atypical for wild-type $E$. coli (Adler, 1966). Unlike the single mutants, the double mutants were attracted little or not at all into capillaries containing D-glucose, D-galactose or D-ribose (data not shown). However, temporal stimulation by $\mathrm{D}$-ribose did produce a behavioural response: addition of $\mathrm{D}$-ribose suppressed the tumbling (see below) induced by indole. 
Negative chemotaxis properties. As expected from the characteristics of the single mutants, the double mutants were not repelled by acetate, benzoate and leucine, or by $\mathrm{Co}^{2+}$ and $\mathrm{Ni}^{2+}$, but addition of indole elicited a weak tumbling response (Table 3). Further, there is evidence that $E$. coli excretes a substance, as yet unidentified, that repels wild-type bacteria (Tso \& Adler, 1974) and also the double mutants (H. Kondoh, unpublished observation).

\section{DISCUSSION}

We have found that the so-called aspartate taxis mutants and serine taxis mutants have additional chemotaxis defects besides the failure to be attracted to aspartate or serine and their analogues: we call them tar and $t s r$ mutants, respectively.

The tar mutants lack positive taxis for aspartate and certain analogues such as $\alpha$-methylaspartate and glutamate, but they retain positive taxis for serine and analogues such as $\alpha$-aminoisobutyrate. They are highly defective in positive taxis for maltose, but other sugars remain attractants to a variable degree. They retain negative taxis for certain repellents (for example, acetate, benzoate, indole, leucine and $\mathrm{H}^{+}$), but they have lost negative taxis for other repellents (for example, $\mathrm{Co}^{2+}$ and $\mathrm{Ni}^{2+}$ ).

The $t s r$ mutants are highly defective in positive taxis for serine and analogues such as $\alpha$-aminoisobutyrate, but aspartate and its analogues and various sugars remain attractants. Certain chemicals (for example, $\mathrm{Co}^{2+}$ and $\mathrm{Ni}^{2+}$ ) remain repellents, but the mutants have lost negative taxis for other repellents (for example, acetate, benzoate, indole and leucine), and instead the bacteria are attracted to nearly all these chemicals (Muskavitch et al., 1978).

Complementarity of tar and tsr pathways. A comparison of the properties of the tar and tsr mutants reveals a complementarity: (i) aspartate and maltose fail to attract the tar mutants but do attract the $t s r$ mutants; (ii) serine fails to attract the $t s r$ mutants normally but does attract the tar mutants; (iii) $\mathrm{Co}^{2+}$ and $\mathrm{Ni}^{2+}$ fail to repel the tar mutants but do repel the $t s r$ mutants; (iv) acetate, benzoate, indole and leucine fail to repel the $t s r$ mutants (indeed they attract) but do repel the tar mutants. This complementarity indicates that certain attractants and repellents are detected by mechanisms that pass information through a component defective in the tar mutants, while other attractants and repellents use a pathway that leads into a component defective in the $t s r$ mutants. Figure 7 illustrates this view of two complementary pathways of information flow - the tar and the $t s r$ pathways.

As shown in Fig. 7, the situation with regard to serine is somewhat more complex than indicated above. Chemotactically wild-type bacteria appear to have two chemoreceptors for serine: a high-affinity system that detects both serine and $\alpha$-aminoisobutyrate, and a lowaffinity system that detects serine but not $\alpha$-aminoisobutyrate (Springer et al., 1977). In the tar mutants, the high-affinity system is functional since these mutants respond to $\alpha$-aminoisobutyrate (Mesibov \& Adler, 1972; Springer et al., 1977), but the low-affinity system is defective which results in the somewhat decreased response to serine observed in the tar strains (Mesibov \& Adler, 1972; Springer et al., 1977; Fig. 1 and Table 2, this report). In the $t s r$ mutants, the high-affinity system is non-functional since $\alpha$-aminoisobutyrate fails to attract the bacteria (Mesibov \& Adler, 1972; Springer et al., 1977), but the low-affinity system is still active, accounting for the residual response to serine seen at high concentrations in both capillary and temporal assays (Mesibov \& Adler, 1972; Springer et al., 1977). This is not evident in Fig. 1 because of the scale used on the ordinate.

As might be expected, double mutants that contain both the tar mutation and the $t s r$ mutation are defective in all the chemotaxes defective in the single mutants. Some tactic responses to a few chemicals do remain in the double mutants. It appears now that certain sugar receptors (for example, galactose and ribose) use an additional pathway different from the $t a r$ and $t s r$ pathways (Kondoh et al., 1979). It seems likely that the response to ribose and the negative chemotaxis that is retained in the double mutants is due to this, or another, additional pathway. The expression of additional pathways is somehow largely blocked 


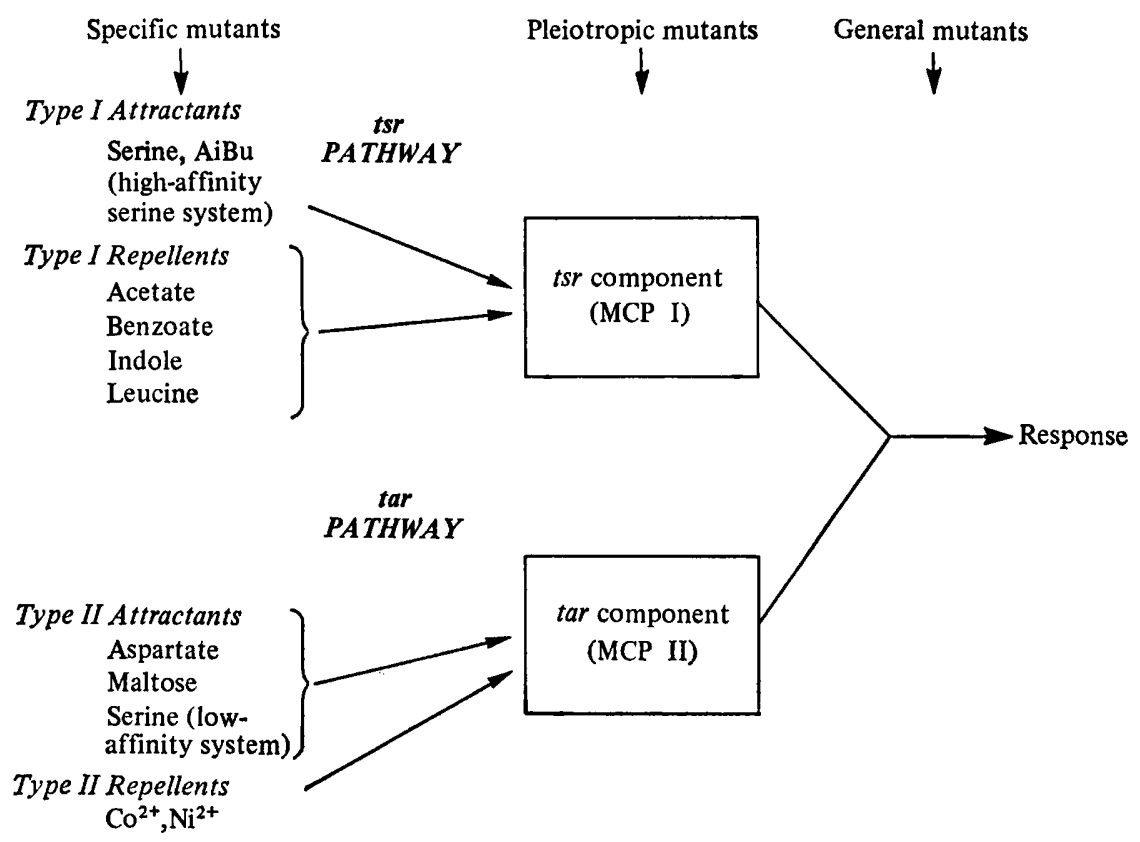

Fig. 7. Proposed mechanism for flow of sensory information from the various chemoreceptors through two components via two complementary routes - the $t s r$ and tar pathways. (AiBu, $\alpha$-aminoisobutyrate.)

in the double mutants used here but not in other double mutants (Kondoh et al, 1979.

Methyl-accepting chemotaxis proteins. Kort et al. (1975) discovered the methylation of a cytoplasmic membrane component, the methyl-accepting chemotaxis protein (MCP), and showed its involvement in chemotaxis. Attractants increase the methylation level of MCP, while repellents decrease it (Goy et al., 1977). Recently it has been demonstrated that this material consists of several polypeptide components (Silverman \& Simon, 1977; Springer et al., 1977). Methylation of certain polypeptides of MCP, the MCP I group, does not occur in the $t s r$ mutants, while methylation of other polypeptides of MCP, the MCP II group, does not occur in the tar mutants; methylation of both groups of MCP polypeptides does not occur in the tsr tar double mutants (Silverman \& Simon, 1977; Springer et al., 1977). Thus it has been possible to identify chemically the two components through which sensory information flows from the $t s r$ and tar pathways (Fig. 7).

There is evidence that MCP I and MCP II interact with each other. Attractants which still attract $t s r$ mutants elicit higher responses in these mutants than in their parent (Mesibov \& Adler, 1972; Springer et al., 1977; Fig. 1 and Table 4, this report), as though the absence of MCP II allows more effective functioning of the MCP I present. Conversely, certain chemicals which attract or repel tar mutants do so more effectively than in wild-type bacteria (Springer et al., 1977). Certain tar mutants (2,3 and 8) are somewhat defective in $t s r$ function (Table 3, this report). It is as if a defective MCP I can interfere with the functioning of MCP II, and vice versa. Possibly MCP I and MCP II may occur together in a complex, and in this way they can influence each other's functioning.

It is not yet clear how the output from the tsr and tar components, MCP I and MCP II, is integrated to produce a response; yet this convergence is necessary since ultimately the flagella must be caused to rotate either clockwise or counterclockwise (Berg, 1974; Berg \& Anderson, 1973; Silverman \& Simon, 1974) in response to sensory stimuli (Larsen et al., 1974).

Types of mutants. Chemotaxis mutants can now be classified into three types (see Fig. 7). 
'Specific mutants' lack taxis only to one chemical or a group of chemicals that are structurally closely related; these mutants lack one chemoreceptor. 'General mutants' are defective in all chemotactic responses, both positive and negative (Armstrong et al., 1967; Tso \& Adler, 1974). These generally non-chemotactic (che) mutants lack the ability to control the methylation level of MCP (Kort et al., 1975; Silverman \& Simon, 1977; Springer et al., 1977) or they lack proper functioning of a final common pathway through which information from MCP must flow. 'Pleiotropic mutants', such as those described in this report, have lost several, but not all, taxes. Another example of the pleiotropic type are the signaller (trg) mutants (Ordal \& Adler, 1974b; Strange \& Koshland, 1976), which do not show taxis to ribose and galactose because they lack a component, MCP III, shared by the ribose and galactose receptors (Kondoh et al., 1979).

Since they have multiple taxis defects, it is unlikely that the pleiotropic aspartate taxis mutants and the pleiotropic serine taxis mutants lack an aspartate receptor or a serine receptor; rather the output from these and other receptors fails to be registered (or in some cases is wrongly registered). Chemoreceptors generally are part of transport systems (Adler, 1975; Hazelbauer \& Adler, 1971), and thus specific mutants, lacking receptors, might be expected to show defects in transport. However, eight tar mutants and twelve tsr mutants tested were indistinguishable from their parents in the transport of $10^{-8}$ to $10^{-6} \mathrm{M} \mathrm{L}$-aspartate or L-serine, respectively (Mesibov \& Adler, 1972; R. W. Reader, unpublished data). Thus the work described in this paper demonstrates that what we thought were receptor mutants (Mesibov \& Adler, 1972) are not. The failure so far to find any specific aspartate or serine taxis mutants is probably due to the multiplicity of transport systems (and hence chemoreceptors) for these amino acids (Oxender, 1972; Schellenberg \& Furlong, 1977; Springer et al., 1977).

The chemoreceptors for amino acids can be divided into two types: those functional in the $t s r$ mutants and those functional in the tar mutants. However, the classification of numerous amino acid attractants into only two chemoreceptors (the 'aspartate receptor' and the 'serine receptor') (Mesibov \& Adler, 1972) must now be considered an oversimplification, in that it was based on the use of pleiotropic mutants. On the other hand, results on the basis of a different criterion - the competition experiment (Adler, 1969; Mesibov \& Adler, 1972) - were in agreement with this classification. (In such an experiment one attractant is placed in a capillary that is inserted into a suspension of motile bacteria, while a second attractant, at a relatively high concentration, is placed both in the capillary and in the bacterial suspension. If the two attractants are detected by the same chemoreceptor, the second attractant should saturate the receptor and in this way prevent taxis toward the first. If the two attractants are detected by different chemoreceptors, taxis toward the first attractant should still take place.) However, competition may not have been at the receptor level, but rather at the level of later components, i.e. those involved in the pleiotropic mutants.

A more accurate, detailed classification of the amino acid attractants into chemoreceptor classes must await the isolation of specific taxis mutants.

We are grateful to Margaret M. Dahl for valuable help in this work. We thank H. Kondoh for unpublished results. This research was supported by National Institutes of Health Training Grant 5-R01-AI08746, a grant from the National Science Foundation PCM75-21007, a grant from U.S. Public Health Service 2-R01-AI08746, and a grant from the Graduate School of the University of Wisconsin-Madison. 


\section{REFERENCES}

Adler, J. (1966). Chemotaxis in bacteria. Science 153, 708-716.

ADLER, J. (1969). Chemoreceptors in bacteria. Science 166, 1588-1597.

ADler, J. (1973). A method for measuring chemotaxis and use of the method to determine optimum conditions for chemotaxis by Escherichia coli. Journal of General Microbiology 74, 77-91.

Adler, J. (1975). Chemotaxis in bacteria. Annual Review of Biochemistry 44, 341-356.

Armstrong, J. B., Adler, J. \& Dahl, M. M. (1967). Nonchemotactic mutants of Escherichia coli. Journal of Bacteriology 93, 390-398.

BERG, H. C. (1974). Dynamic properties of bacterial flagellar motors. Nature 249, 77-79.

Berg, H. C. \& Anderson, R. A. (1973). Bacteria swim by rotating their flagellar filaments. Nature, London 245, 380-382.

Goy, M. F., Springer, M. S. \& Adler, J. (1977). Sensory transduction in Escherichia coli: role of a protein methylation reaction in sensory adaptation. Proceedings of the National Academy of Sciences of the United States of America 74, 4964-4968.

Hazelbauer, G. L. \& Adler, J. (1971). Role of the galactose binding protein in chemotaxis of Escherichia coli toward galactose. Nature New Biology 230, 101-104.

Hazelbauer, G. L., Mesibov, R. E. \& Adler, J. (1969). Escherichia coli mutants defective in chemotaxis toward specific chemicals. Proceedings of the National Academy of Sciences of the United States of America 64, 1300-1307.

KondoH, H., Ball, C. B. \& ADler, J. (1979). Identification of a methyl-accepting chemotaxis protein for the ribose and galactose chemoreceptors in Escherichia coli. Proceedings of the National Academy of Sciences of the United States of America 76, 260-264.

Kort, E. N., GoY, M. F., LARSEN, S. H. \& Adler, J. (1975). Methylation of a membrane protein involved in bacterial chemotaxis. Proceedings of the National Academy of Sciences of the United States of America 72, 3939-3943.

Larsen, S. H., Reader, R. W., Kort, E. N., Tso, W. W. \& AdLer, J. (1974). Change in direction of flagellar rotation is the basis of the chemotactic response in Escherichia coli. Nature, London 249, 74-77.

MaCNAB, R. M. \& Koshland, D. E., JR (1972). The gradient-sensing mechanism in bacterial chemotaxis. Proceedings of the National Academy of Sciences of the United States of America 69, 2509-2512.

Mestbov, R. \& Adler, J. (1972). Chemotaxis towards amino acids in Escherichia coli. Journal of Bacteriology 112, 315-326.
Muskavitch, M. A., Kort, E. N., Springer, M. S., GOY, M. F. \& ADLER, J. (1978). Attraction by repellents: an error in sensory information processing by bacterial mutants. Science 201, 63-65.

ORDAL, G. W. \& ADLER, J. (1974a). Isolation and complementation of mutants in galactose taxis and transport. Journal of Bacteriology 117, 509516.

Ordal, G. W. \& Adler, J. (1974b). Properties of mutants in galactose taxis and transport. Journal of Bacteriology 117, 517-526.

OXENDER, D. A. (1972). Amino acid transport in microorganisms. In Metabolic Pathways, vol. 6, Metabolic Transport, 3rd edn, pp. 133-185. Edited by L. E. Hokin. New York: Academic Press.

Parkinson, J. S. (1975). Genetics of chemotactic behaviour in bacteria. Cell 4, 183-188.

Parkinson, J. S. (1977). Behavioural genetics in bacteria. Annual Review of Genetics 11, 397-414.

Schellenberg, G. D. \& Furlong, C. E. (1977). Resolution of the multiplicity of the glutamate and aspartate transport systems of Escherichia coli. Journal of Biological Chemistry 252, 90559064.

Silverman, M. \& Simon, M. (1974). Flagellar rotation and the mechanism of bacterial motility. Nature, London 249, 73-74.

Silverman, M. \& Simon, M. (1977). Chemotaxis in Escherichia coli: methylation of che gene products. Proceedings of the National Academy of Sciences of the United States of America 74, 3317-3321.

Springer, M. S., GoY, M. F. \& AdLer, J. (1977). Sensory transduction in Escherichia coli: two complementary pathways of information processing that involve methylated proteins. Proceedings of the National Academy of Sciences of the United States of America 74, 3312-3316.

Strange, P. G. \& Koshland, D. E., JR (1976). Receptor interactions in a signalling system: competition between ribose receptor and galactose receptor in the chemotaxis response. Proceedings of the National Academy of Sciences of the United States of America 73, 762-766.

Tsang, N., Macnab, R. \& Koshland, D. E., JR (1973). Common mechanism for repellents and attractants in bacterial chemotaxis. Science 181, 60-63.

Tso, W. W. \& Adler, J. (1974). Negative chemotaxis in Escherichia coli. Journal of Bacteriology 118, 560-576.

WARrick, H. M., TAYLOR, B. L. \& Koshland, D. E., JR (1977). Chemotactic mechanism of Salmonella typhimurium: preliminary mapping and characterization of mutants. Journal of Bacteriology 130, 223-231. 